\title{
PROFIL PENDERITA TUMOR KELENJAR LIUR DI RSUP PROF. DR. R.D. KANDOU MANADO PERIODE JULI 2012-JUNI 2015
}

\author{
${ }^{1}$ Wirawan Iman \\ ${ }^{2}$ Marselus Merung \\ ${ }^{2}$ Ainun Aschorijanto \\ ${ }^{1}$ Mahasiswa Fakultas Kedokteran Universitas Sam Ratulangi Manado \\ ${ }^{2}$ Dosen Ilmu Bedah Fakultas Kedokteran Universitas Sam Ratulangi Manado \\ Email : wirawaniman.12160@gmail.com
}

\begin{abstract}
Salivary glands tumours are relatively rare to find. There is still no adequate data about the incidence of salivary gland tumours in Indonesia. The main objective of this research was to cognise the profile of salivary glands tumours patients in Prof. Dr. R.D. Kandou Central General Hospital Manado from July 2012 to June 2015. Methods used is descriptive retrospective. The results showed there are 37 patients with salivary gland(s) tumour(s). Male was 59,5\% and female was 40,5\%. By age groups found that <19 years for 2.7\%, 19-30 years for 8,2\%, 31-45 years for $21.6 \%$, 46-60 years for 37,8\%, >60 years for 29,7\%. Based on the histopathological classification, pleomorphic adenoma for 56.8\%, Whartin's tumor for $8.1 \%$, myoepithelioma for 2,7\%, basal cell adenoma for $2.7 \%$, oncocytoma for $2.7 \%$, cystadenoma for $5.4 \%$, canalicular adenoma for $2.7 \%$, mucoepidermoid carcinoma for $10.8 \%$, adenocarcinoma for $5.4 \%$, and acinic cell carcinoma for $2.7 \%$. Based on the location of the tumours' appearance, parotid gland for $83.8 \%$, submandibular gland for $13.5 \%$, minor salivary glands for $2.7 \%$. Based by the incidences annually, first year for $21.6 \%$, second year for $32.3 \%$, and the third year for $46.1 \%$.

Conclusion: Males are more than females, most commonly found in the age group of 51-60 years, the most commonly benign tumour found is the pleomorphic adenoma, the most commonly found malign tumour is mucoepidermoid carcinoma, the most commonly location of the tumours' appearance is the parotid gland. The salivary glands tumours continued to increase during the last three years.
\end{abstract}

Suggestion: Still necessary to do further research about salivary glands tumours. Keywords: salivary glands tumours, age, gender, histopathology, location, profile

Abstrak : Tumor kelenjar liur adalah tumor yang relatif sedikit dijumpai ditemukan. Belum ditemukan data yang lengkap tentang kejadian tumor kelenjar liur di Indonesia. Tujuan utama dari penelitian ini adalah untuk mengetahui profil penderita tumor kelenjar liur di RSUP Prof. Dr. R.D. Kandou Manado periode Juli 2012-Juni 2015. Metode penelitian yang digunakan adalah deskriptif retrospektif. Hasil penelitian memperlihatkan terdapat 37 penderita tumor kelenjar liur. Laki-laki sebanyak 59,5\% dan perempuan 40,5\%. Kelompok usia $<16$ tahun sebanyak 2,7\%, 16-30 tahun sebanyak 8,1\%, 31-45 tahun sebanyak 21,6\%, 46-60 tahun sebanyak 37,8\%, >60 tahun sebanyak 29,7\%. Berdasarkan klasifikasi histopatologi jenis pleomorphic adenoma sebanyak $56,8 \%$, Whartin's tumor sebanyak 8,2\%, myoepithelioma sebanyak 2,7\%, basal cell adenoma sebanyak 2,7\%, oncocytoma sebanyak 2,7\%, cystadenoma sebanyak 5,4\%, canalicular adenoma sebanyak 2,7\%, mucoepidermoid carcinoma sebanyak 10,8\%, adenocarcinoma sebanyak 5,4\%, acinic cell carcinoma sebanyak 2,7\%. Berdasarkan lokasi munculnya tumor, kelenjar parotis sebanyak 83,8\%, kelenjar submandibula 
sebanyak 13,5\%, kelenjar liur minor sebanyak 2,7\%. Berdasarkan jumlah pertahunnya, tahun pertama sebanyak 21,6\%, tahun kedua sebanyak 32,3\%, dan tahun ketiga sebanyak 46,1\%.

Kesimpulan : Penderita laki-laki lebih banyak daripada perempuan, paling banyak ditemukan pada kelompok usia 46-60 tahun, tumor jinak yang paling banyak ditemukan adalah pleomorphic adenoma, tumor ganas yang paling banyak ditemukan adalah mucoepidermoid carcinoma, lokasi tersering munculnya tumor adalah kelenjar parotis. Penderita tumor kelenjar liur terus meningkat selama tiga tahun terakhir.

Saran : Perlu dilakukan penelitian lebih lanjut tentang tumor kelenjar liur

Kata Kunci : tumor kelenjar liur, usia, jenis kelamin, histopatologi, lokasi, profil

Kejadian tumor kelenjar liur merupakan 3-6\% dari semua kejadian tumor di kepala dan leher. Dari semua insiden tumor kelenjar liur, kurang lebih 80\% berasal dari kelenjar parotis, $10-15 \%$ dari kelenjar submandibula, sekitar 5-8\% dari kelenjar minor, dan $<1 \%$ berasal dari kelenjar sublingual. Tumor kelenjar liur yang paling banyak didapati adalah tumor jinak pleomorphic adenoma dan merupakan $75-80 \%$ dari tumor pada kelenjar parotis. ${ }^{1-3}$

Tumor ganas pada kelenjar liur merupakan 5-7\% dari semua kejadian tumor ganas di kepala dan leher. Jenis tersering di kelenjar parotis adalah mucoepidermoid carcinoma, yang merupakan $10 \%$ dari semua kejadian tumor kelenjar liur dan juga merupakan $35 \%$ dari semua kejadian tumor ganas kelenjar liur. ${ }^{2,4}$ Kelenjar submandibula memiliki insiden tumor ganas kurang dari $50 \%$ dengan jenis tersering adenocarcinoma yang juga merupakan jenis tumor ganas yang didapati pada semua kelenjar liur minor. Tumor pada kelenjar sublingual hampir selalu merupakan tumor ganas. ${ }^{1-3,5,6}$ Acinic cell carcinoma merupakan tumor kelenjar liur yang jarang terjadi, hanya sekitar 2-4\% dari semua tumor pada kelenjar parotis. Sebagian besar acinic cell carcinoma berasal dari kelenjar parotis (83\%). Sekitar $17 \%$ didapati di kelenjar ludah minor pada intra oral. Hanya sekitar 4\% berasal dari kelenjar submandibular dan kurang dari $1 \%$ berasal dari kelenjar

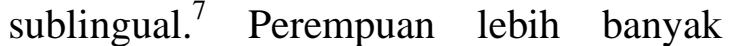
menderita acinic cell carcinoma daripada laki-laki (3:1). ${ }^{8}$

Dibandingkan dengan tumor ganas lainnya, tumor ganas kelenjar liur relatif jarang di Amerika Serikat. Pada tahun 2008, hanya sekitar $12 \%$ dari tumor ganas mulut \& faring. Beberapa kasus juga telah dilaporkan di daerah-daerah dengan radiasi ultraviolet yang tinggi. Beberapa tahun terakhir, insiden tumor ganas kelnjar liur juga perlahan-lahan meningkat sekitar 1-2\% pertahun. Meskipun ada kemungkinan untuk tumor ganas kelenjar ludah terjadi pada penderita dari semua jenis usia, duapertiga tumor ganas kelenjar liur ditemukan pada penderita denga usia 55 tahun keatas. Rata-rata, tumor ganas kelenjar liur terdiagnosa pada usia 64 tahun. ${ }^{9}$

Badan Registrasi Tumor ganas Indonesia melaporkan adanya kejadian tumor kelenjar liur sebanyak 120 kasus pada tahun 2005 yang terjadi di Sumatera, Jawa, Bali, dan Kalimantan. ${ }^{10}$ Badan Registrasi Tumor ganas Indonesia juga melaporkan bahwa sepanjang tahun 20032007 didapati 82 kasus tumor ganas pada kelenjar liur di RS Tumor ganas Dharmais dengan jenis tumor ganas terbanyak adalah mucoepidermoid carcinoma sebanyak 16 kasus. $^{11}$

Di Indonesia sendiri masih belum terdapat data yang lengkap tentang kasus tumor kelenjar liur, baik itu tumor jinak maupun tumor ganas. Data yang menghubungkan jenis kelamin dan usia 
dengan kasus tumor kelenjar liur juga belum lengkap. ${ }^{2}$ Hal ini mendorong penulis untuk melakukan penelitian tentang profil penderita tumor kelenjar liur di RSUP Prof. Dr. R.D. Kandou.

\section{METODE PENELITIAN}

Metode penelitian ini bersifat deskriptif retrospektif. Penelitian ini dilakukan di RSUP Prof. Dr. R.D. Kandou Manado. Seluruh data penderita tumor kelenjar liur yang terdapat pada rekam medik RSUP Prof. Dr. R.D. Kandou Manado periode Juli 2012 hingga Juni 2015 menjadi subjek penelitian ini. Alat dan bahan yang digunakan adalah data rekam medik penderita tumor kelenjar liur di RSUP Prof. Dr. R.D. Kandou Manado periode Juli 2012-Juni 2015, literaturliteratur yang berhubungan dengan karya tulis ilmiah, laptop dan alat tulis menulis. Variabel Penelitian yang diteliti yaitu :

1. Jenis kelamin

2. Usia

3. Klasifikasi histopatologi

4. Lokasi tumor

5. Jumlah penderita pertahun

Cara kerja penelitian ini yaitu melakukan pengumpulan data dengan melihat arsip data rekam medik penderita tumor kelenjar liur yang ada di RSUP Prof. Dr. R.D. Kandou Manado. Data yang terkumpul kemudian disajikan dalam bentuk tulisan, tabel dan gambar.

\section{HASIL PENELITIAN}

Hasil penelitian yang penulis lakukan di RSUP Prof. Dr. R.D. Kandou Manado sejak 21 Oktober hingga 21 Desember 2015 memperlihatkan hasil dimana terdapat 37 penderita tumor kelenjar liur.

Tabel 1. Distribusi jumlah penderita tumor kelenjar liur menurut jenis kelamin.

\begin{tabular}{ccc}
\hline $\begin{array}{c}\text { Jenis } \\
\text { Kelamin }\end{array}$ & $\begin{array}{c}\text { Jumlah } \\
\text { Penderita }\end{array}$ & Persentase \\
\hline Laki-laki & 22 & $59,5 \%$ \\
Perempuan & 15 & $40,5 \%$ \\
\hline Total & 37 & $100 \%$ \\
\hline
\end{tabular}

Tabel 1 memperlihatkan 37 penderita tumor kelenjar liur, 22 diantaranya berjenis kelamin laki-laki dan 15 sisanya berjenis kelamin perempuan.

Tabel 2. Distribusi jumlah penderita tumor kelenjar liur menurut kelompok usia dan sifat tumor.

\begin{tabular}{ccccc}
\hline \multirow{2}{*}{ Usia } & \multicolumn{2}{c}{ Sifat Tumor } & Jumlah & Persentase \\
\cline { 2 - 3 } & Jinak & Ganas & Penderita & \\
\hline$<16$ & 1 & - & 1 & $2,7 \%$ \\
$16-30$ & 2 & 1 & 3 & $8,2 \%$ \\
$31-45$ & 6 & 2 & 8 & $21,6 \%$ \\
$46-60$ & 12 & 2 & 14 & $37,8 \%$ \\
$>60$ & 9 & 2 & 11 & $29,7 \%$ \\
\hline Total & 30 & 7 & 37 & $100 \%$ \\
\hline
\end{tabular}

Tabel 2 memperlihatkan jumlah penderita tumor kelenjar liur paling banyak terdapat pada pasien dengan kelompok usia 46-60 tahun, yaitu sebanyak 14 penderita (37,8\%) dengan 12 penderita $(85,7 \%)$ tumor jinak dan dua penderita $(14,3 \%)$ tumor ganas, sedangkan yang paling sedikit ditemukan pada kelompok usia $<16$ tahun yaitu sebanyak satu penderita (2,7\%) saja dengan sifat tumor jinak. Kelompok usia 16-30 tahun terdapat tiga penderita $(8,2 \%)$ yang terdiri dari dua penderita $(66,7 \%)$ tumor jinak dan satu penderita $(33,3 \%)$ tumor ganas. 
Kelompok usia 31-45 tahun terdapat delapan penderita $(21,6 \%)$ yang terdiri dari enam penderita $(75 \%)$ tumor jinak dan dua penderita (25\%) tumor ganas. Kelompok usia $>60$ tahun tahun terdapat
11 penderita (29,7\%) yang terdiri dari Sembilan penderita $(81,8 \%)$ tumor jinak dan dua penderita $(18,2 \%)$ tumor ganas.

Tabel 3. Distribusi jumlah penderita tumor kelenjar liur menurut klasifikasi histopatologi dihubungkan dengan lokasi munculnya tumor.

\begin{tabular}{ccccc}
\hline $\begin{array}{c}\text { Klasifikasi } \\
\text { Histopatologi }\end{array}$ & Parotis & Submandibula & $\begin{array}{c}\text { Kelenjar } \\
\text { liur minor }\end{array}$ & Total \\
\hline $\begin{array}{c}\text { Tumor Jinak } \\
\text { Pleomorphic }\end{array}$ & $17(54,8 \%)$ & $3(60 \%)$ & 1 & $21(56,8 \%)$ \\
$\begin{array}{c}\text { adenoma } \\
\text { Whartin's } \\
\text { tumour }\end{array}$ & $3(9,7 \%)$ & - & - & $3(8,1 \%)$ \\
$\begin{array}{c}\text { Myoepithelioma } \\
\text { Basal cell }\end{array}$ & - & $1(20 \%)$ & - & $1(2,7 \%)$ \\
$\begin{array}{c}\text { adenoma } \\
\text { Oncocytoma }\end{array}$ & $1(3,2 \%)$ & - & - & $1(2,7 \%)$ \\
$\begin{array}{c}\text { Cystadenoma } \\
\text { Canalicular } \\
\text { adenoma }\end{array}$ & $1(3,2 \%)$ & - & - & $1(2,7 \%)$ \\
\hline $\begin{array}{c}\text { Tumor Ganas } \\
\text { Mucoepidermoid }\end{array}$ & $1(3,2 \%)$ & - & - & $2(5,4 \%)$ \\
$\begin{array}{c}\text { carcinoma } \\
\text { Adenocarcinoma }\end{array}$ & $2(6,5 \%)$ & - & - & $1(2,7 \%)$ \\
$\begin{array}{c}\text { Acinic cell } \\
\text { carcinoma }\end{array}$ & $1(3,2 \%)$ & - & - & $4(10,8 \%)$ \\
\hline \begin{tabular}{c} 
Total \\
\hline
\end{tabular} & $31(83,8 \%)$ & $5(13,5 \%)$ & $1(2,7 \%)$ & $37(100 \%)$ \\
\hline
\end{tabular}

Tabel 3 memperlihatkan 37 penderita mucoepidermoid carcinoma terdapat tumor kelenjar liur, 30 diantaranya $(81,1 \%)$ menderita tumor jinak dan tujuh penderita (18,9\%) sisanya menderita tumor ganas. Pleomorphic adenoma terdapat 21 penderita (56,8\%), Whartin's tumour terdapat tiga penderita $(8,1 \%)$, myoepithelioma terdapat satu penderita (2,7\%), basal cell adenoma terdapat satu penderita $(2,7 \%)$, oncocytoma terdapat satu penderita (2,7\%), cystadenoma terdapat dua penderita $(5,4 \%)$, canalicular empat penderita $(10,8 \%)$, adenocarcinoma terdapat dua penderita (5,4\%) dan acinic cell carcinoma terdapat satu penderita (2,7\%) saja.

Tabel diatas juga memperlihatkan lokasi tersering munculnya tumor kelenjar liur adalah kelenjar parotis yaitu sebanyak 31 penderita (83,8\%), diikuti oleh kelenjar submandibula sebanyak lima penderita (13,5\%), dan paling sedikit pada kelenjar liur minor hanya satu penderita (2,7\%). adenoma terdapat satu penderita (2,7\%), 
Tabel 4. Distribusi jumlah penderita tumor kelenjar liur menurut klasifikasi histopatologi dihubungkan dengan kelompok usia penderita.

\begin{tabular}{|c|c|c|c|}
\hline \multirow{2}{*}{$\begin{array}{c}\text { Klasifikasi } \\
\text { Histopatologi }\end{array}$} & \multicolumn{3}{|c|}{ Kelompok Usia } \\
\hline & $<16$ & $16-30$ & $31-45$ \\
\hline \multicolumn{4}{|l|}{ Tumor Jinak } \\
\hline $\begin{array}{l}\text { Pleomorphic } \\
\text { adenoma }\end{array}$ & $1(4,8 \%)$ & $2(9,5 \%)$ & $5(23,8 \%)$ \\
\hline $\begin{array}{l}\text { Whartin's } \\
\text { tumour }\end{array}$ & - & - & $1(33,3 \%)$ \\
\hline Myоерithelioma & - & - & - \\
\hline $\begin{array}{l}\text { Basal cell } \\
\text { adenoma }\end{array}$ & - & - & - \\
\hline Oncocytoma & - & - & - \\
\hline Cystadenoma & - & - & - \\
\hline $\begin{array}{l}\text { Canalicular } \\
\text { adenoma }\end{array}$ & - & - & - \\
\hline \multicolumn{4}{|l|}{ Tumor Ganas } \\
\hline $\begin{array}{l}\text { Mucoepidermoid } \\
\text { carcinoma }\end{array}$ & - & $1(25 \%)$ & - \\
\hline Adenocarcinoma & - & - & $1(50 \%)$ \\
\hline $\begin{array}{l}\text { Acinic cell } \\
\text { carcinoma }\end{array}$ & - & - & 1 \\
\hline Klasifikasi & \multicolumn{3}{|c|}{ Kelompok Usia } \\
\hline Histopatologi & $46-60$ & $>60$ & Total \\
\hline \multicolumn{4}{|l|}{ Tumor Jinak } \\
\hline $\begin{array}{l}\text { Pleomorphic } \\
\text { adenoma }\end{array}$ & $7(33,3 \%)$ & $6(28,6 \%)$ & $21(56,8 \%)$ \\
\hline $\begin{array}{l}\text { Whartin's } \\
\text { tumour }\end{array}$ & $1(33,3 \%)$ & $1(33,3 \%)$ & $3(8,1 \%)$ \\
\hline Myоерithelioma & - & 1 & $1(2,7 \%)$ \\
\hline $\begin{array}{l}\text { Basal cell } \\
\text { adenoma }\end{array}$ & 1 & - & $1(2,7 \%)$ \\
\hline Oncocytoma & 1 & - & $1(2,7 \%)$ \\
\hline Cystadenoma & $1(50 \%)$ & $1(50 \%)$ & $2(5,4 \%)$ \\
\hline $\begin{array}{c}\text { Canalicular } \\
\text { adenoma }\end{array}$ & 1 & - & $1(2,7 \%)$ \\
\hline \multicolumn{4}{|l|}{ Tumor Ganas } \\
\hline $\begin{array}{l}\text { Mucoepidermoid } \\
\text { carcinoma }\end{array}$ & $1(25 \%)$ & $2(50 \%)$ & $4(10,8 \%)$ \\
\hline Adenocarcinoma & $1(50 \%)$ & - & $2(5,4 \%)$ \\
\hline $\begin{array}{l}\text { Acinic cell } \\
\text { carcinoma }\end{array}$ & - & - & $1(2,7 \%)$ \\
\hline Total & & & $37(100 \%)$ \\
\hline
\end{tabular}

Tabel 4 memperlihatkan penderita pleomorphic adenoma pada kelompok usia 46-60 tahun terdapat tujuh penderita
(33,3\%), kelompok usia >60 tahun terdapat enam penderita $(28,6 \%)$, kelompok usia 31-45 tahun terdapat lima penderita (23,8\%), kelompok usia 16-30 
tahun terdapat dua penderita (9,5\%), kelompok usia $<16$ tahun terdapat satu penderita $(4,8 \%)$ saja. Whartin's tumour terdapat tiga penderita yang terdiri dari satu penderita pada kelompok usia 31-45 tahun, satu penderita pada kelompok usia 46-60 tahun, dan satunya lagi pada kelompok usia >60 tahun. Myopeithelioma terdapat satu penderita pada kelompok usia $>60$ tahun. Basal cell adenoma terdapat satu penderita pada kelompok usia 46-60 tahun. Oncocytoma terdapat satu penderita pada kelompok usia 46-60 tahun. Canalicular adenoma terdapat satu penderita pada kelompok usia 46-60 tahun. Cystadenoma terdapat dua penderita yang terdiri dari satu penderita pada kelompok usia 46-60 tahun dan satu pada kelompok usia $>60$ tahun. Mucoepidermoid carcinoma terdapat dua penderita pada kelompok usia $>60$ tahun, satu penderita pada kelompok usia 46-60 tahun dan satu penderita pada kelompok usia 16-30 tahun. Adenocarcinoma terdapat dua penderita yang terdiri dari satu penderita pada kelompok usia 31-45 tahun dan satu penderita pada kelompok usia 46-60 tahun. Acinic cell carcinoma terdapat satu penderita pada kelompok usia 31-45 tahun.

Tabel 5. Distribusi jumlah penderita tumor kelenjar liur berdasarkan klasifikasi histopatologi dihubungkan dengan jenis kelamin penderita.

\begin{tabular}{cccc}
\hline Klasifikasi & \multicolumn{3}{c}{ Jenis Kelamin } \\
\cline { 2 - 4 } Histopatologi & Laki-laki & Perempuan & Total \\
\hline Tumor Jinak & & & \\
Pleomorphic & $14(66,7 \%)$ & $7(33,3 \%)$ & $21(56,8 \%)$ \\
$\begin{array}{c}\text { adenoma } \\
\text { Whartin's tumour }\end{array}$ & $2(66,6 \%)$ & $1(33,3 \%)$ & $3(8,1 \%)$ \\
Myoepithelioma & 1 & - & $1(2,7 \%)$ \\
Basal cell & - & 1 & $1(2,7 \%)$ \\
adenoma & - & 1 & $1(2,7 \%)$ \\
$\begin{array}{c}\text { Oncocytoma } \\
\text { Cystadenoma } \\
\text { Canalicular }\end{array}$ & $1(50 \%)$ & $1(50 \%)$ & $2(5,4 \%)$ \\
adenoma & 1 & - & $1(2,7 \%)$ \\
\hline $\begin{array}{c}\text { Tumor ganas } \\
\text { Mucoepidermoid }\end{array}$ & $2(50 \%)$ & $2(50 \%)$ & $4(10,8 \%)$ \\
carcinoma & $1(50 \%)$ & $1(50 \%)$ & $2(5,4 \%)$ \\
Adenocarcinoma & & 1 & $1(2,7 \%)$ \\
\hline $\begin{array}{c}\text { Acinic cell } \\
\text { carcinoma }\end{array}$ & - & & $37(100 \%)$ \\
\hline Total & & &
\end{tabular}

Tabel 5 memperlihatkan pleomorphic adenoma terdapat 14 penderita laki-laki $(66,7 \%)$ dan tujuh penderita perempuan (33,3\%). Whartin's tumour terdapat dua penderita laki-laki dan satu penderita perempuan. Myoepithelioma terdapat satu penderita laki-laki. Basal cell adenoma terdapat satu penderita perempuan. Oncocytoma terdapat satu penderita perempuan. Cystadenoma terdapat satu penderita laki-laki dan satu penderita perempuan. Canalicular adenoma terdapat satu penderita laki-laki. 
Mucoepidermoid carcinoma terdapat dua penderita laki-laki dan dua penderita perempuan. Adenocarcinoma terdapat satu penderita laki-laki dan satu penderita perempuan. Acinic cell carcinoma terdapat satu penderita perempuan.

Gambar 1. Distribusi jumlah penderita tumor kelenjar liur pertahun dalam periode Juli 2012-Juni 2015.

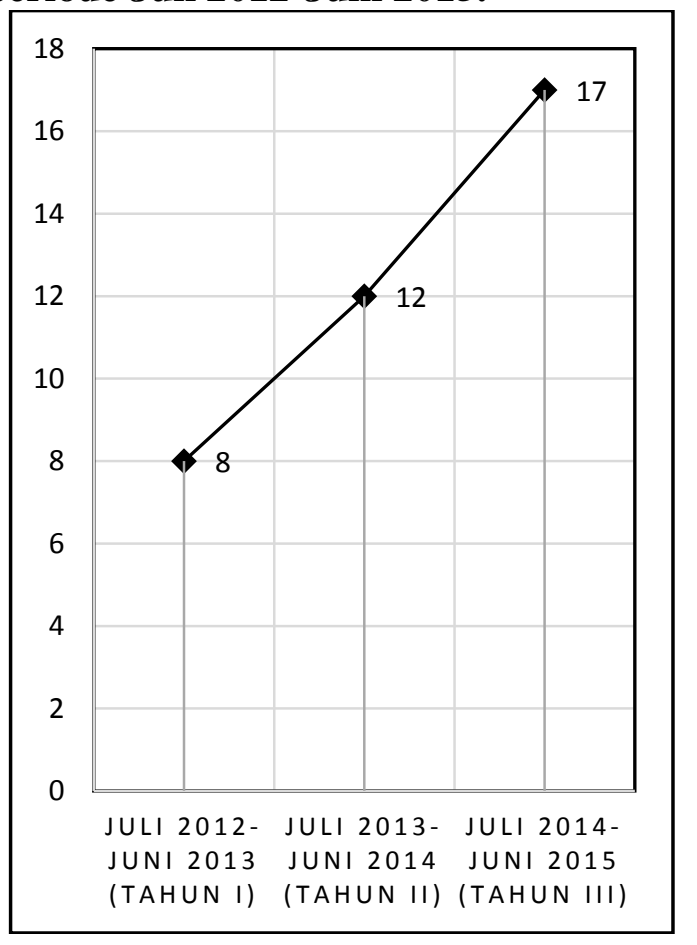

Gambar 1 memperlihatkan jumlah penderita tumor kelenjar liur pertahun dalam periode Juli 2012-Juni 2015. Tahun pertama terdapat delapan penderita (21,6\%). Tahun kedua terdapat 12 penderita (32,3\%). Tahun ketiga terdapat 17 penderita $(46,1 \%)$.

\section{PEMBAHASAN}

Sampel yang diteliti adalah pasien yang didiagnosa menderita tumor kelenjar liur pada rekam medik RSUP Prof. Dr. R.D. Kandou Manado selama periode Juli 2012-Juni 2015. Hasil penelitian penulis memperlihatkan jumlah penderita tumor kelenjar liur sebanyak 37 penderita yang terdiri dari 22 penderita (59,5\%) berjenis kelamin laki-laki dan 15 penderita
(40,5\%) berjenis kelamin perempuan. Terlihat bahwa penderita laki-laki lebih banyak daripada penderita perempuan. Hal ini tidak sama dengan penelitian Ito FA et al. ${ }^{12}$ pada tahun 2005 yang mendapati perempuan lebih banyak daripada laki-laki. Di Indonesia penulis belum menemukan penelitian yang menghubungkan jenis kelamin dan tumor kelenjar liur.

Tabel 2 memperlihatkan tumor kelenjar liur paling banyak terjadi pada pasien dengan kelompok usia 46-60 tahun, yaitu sebanyak 14 penderita $(37,8 \%)$ dengan 12 penderita $(85,7 \%)$ tumor jinak dan dua penderita $(14,3 \%)$ tumor ganas, sedangkan yang paling sedikit terdapat pada kelompok usia <16 tahun yaitu sebanyak satu penderita (2,7\%) saja dengan sifat tumor jinak. Kelompok usia 16-30 tahun terdapat tiga penderita $(8,2 \%)$ yang terdiri dari dua penderita $(66,7 \%)$ tumor jinak dan satu penderita $(33,3 \%)$ tumor ganas. Kelompok usia 31-45 tahun terdapat delapan penderita $(10,8 \%)$ yang terdiri dari enam penderita (75\%) tumor jinak dan dua penderita (25\%) tumor ganas. Kelompok usia $>60$ tahun terdapat 11 penderita (29,7\%) yang terdiri dari sembilan penderita $(81,8 \%)$ tumor jinak dan dua penderita $(18,2 \%)$ tumor ganas. Kelompok usia $<16$ tahun terdapat dua penderita $(5,4 \%)$ dengan sifat tumor jinak. Hasil yang ditemukan ini sesuai dengan laporan Pinkston JA et al. ${ }^{13}$ bahwa insiden tumor kelenjar liur terus meningkat sesuai usia.

Kelompok usia $<16$ tahun hanya ditemui satu penderita tumor kelenjar liur saja. Hal ini sama dengan laporan Lee S.C. ${ }^{6}$ bahwa tumor kelenjar liur jarang terjadi pada anak-anak.

Tabel 3 memperlihatkan 30 penderita $(81,1 \%)$ tumor jinak dan tujuh penderita $(18,9 \%)$ tumor ganas. Pleomorphic adenoma merupakan tumor jinak yang paling banyak didapati dengan jumlah 21 penderita (70\%), diikuti oleh Whartin's 
tumour sebanyak tiga penderita (10\%). Hal ini sama dengan laporan Speight PM et al. $^{4}$ bahwa tumor jinak kelenjar liur yang paling sering ditemui adalah pleomorphic adenoma kemudian Whartin's tumour.

Tabel 3 memperlihatkan tumor jinak (81,1\%) lebih banyak ditemukan daripada tumor ganas (18,9\%). Hal ini sama dengan laporan Vargas PA et al. ${ }^{14}$ bahwa pada tahun 2002, dari 124 kasus tumor kelenjar liur, sebanyak 99 kasus (80\%) merupakan tumor jinak dan 25 kasus (20\%) lainnya merupakan tumor ganas. Jenis pleomorphic adenoma mendominasi sebanyak 84 kasus (59\%) dan sebanyak 13 kasus (10,5\%) merupakan Whartin's tumor. Ito FA et al. ${ }^{12}$ melaporkan pada tahun 2005 terdapat 335 kasus (67,5\%) tumor jinak dan 161 kasus (32,5\%) tumor ganas dari 496 kasus tumor kelenjar liur.

Hasil penelitian

penulis memperlihatkan tujuh penderita $(18,9 \%)$ tumor ganas kelenjar liur dan terbanyak didapati pada jenis mucoepidermoid carcinoma sebanyak empat penderita (57,2\%), kemudian adenocarcinoma sebanyak dua penderita (28,5\%) dan acinic cell carcinoma sebanyak satu penderita $(14,3 \%)$ saja. Hal ini sama dengan laporan Speight PM et al. ${ }^{5}$ bahwa mucoepidermoid carcinoma merupakan tumor ganas tersering pada kelenjar liur yang menempati 35\% dari semua kejadian tumor ganas kelenjar liur. Hal ini juga sama dengan apa yang dillaporan oleh Pinkston et al. ${ }^{13}$ bahwa mucoepidermoid carcinoma menempati 51,3\% dari seluruh kejadian tumor ganas kelenjar liur, dan juga sama dengan laporan Vargas PA et al. ${ }^{14}$ dimana mucoepidermoid carcinoma menempati $52 \%$ dari semua tumor ganas kelenjar liur. Di RS Kanker Dharmais ${ }^{13}$ juga dilaporkan bahwa tumor ganas terbanyak adalah jenis mucoepidermoid carcinoma.

Tabel 3 memperlihatkan 83,8\% tumor kelenjar liur didapati pada kelenjar parotis, $13,5 \%$ pada kelenjar sub mandibula dan 2,7\% pada kelenjar liur minor. Hal sama dengan laporan Futran ND et al. ${ }^{3}$ yang menyebutkan bahwa $80 \%$ tumor kelenjar liur berada di kelenjar parotis, $\quad 10-15 \%$ pada kelenjar submandibula dan 5-8\% pada kelenjar liur minor. Acinic cell carcinoma hanya didapati satu penderita (3,2\%), sesuai dengan laporan Lumongga $F^{7}$ bahwa acinic cell carcinoma sangat jarang terjadi, hanya sekitar 2-4\% dari semua tumor pada kelenjar parotis.

Tabel 4 memperlihatkan penderita pleomorphic adenoma pada kelompok usia 46-60 tahun terdapat tujuh penderita (33,3\%), kelompok usia $>60$ tahun terdapat enam penderita (28,6\%), kelompok usia 31-45 tahun terdapat lima penderita (23,8\%), kelompok usia 16-30 tahun terdapat dua penderita (9,5\%), kelompok usia $<16$ tahun terdapat satu penderita $(4,8 \%)$ saja. Whartin's tumour terdapat tiga penderita yang terdiri dari satu penderita pada kelompok usia 31-45 tahun, satu penderita pada kelompok usia 46-60 tahun, dan satunya lagi pada kelompok usia >60 tahun. Myopeithelioma terdapat satu penderita pada kelompok usia $>60$ tahun. Basal cell adenoma terdapat satu penderita pada kelompok usia 46-60 tahun. Oncocytoma terdapat satu penderita pada kelompok usia 46-60 tahun. Canalicular adenoma terdapat satu penderita pada kelompok usia 46-60 tahun. Cystadenoma terdapat dua penderita yang terdiri dari satu penderita pada kelompok usia 46-60 tahun dan satu pada kelompok usia $>60$ tahun. Mucoepidermoid carcinoma terdapat dua penderita pada kelompok usia $>60$ tahun, satu penderita pada kelompok usia 46-60 tahun dan satu penderita pada kelompok usia 16-30 tahun. Adenocarcinoma terdapat dua penderita yang terdiri dari satu penderita pada kelompok usia 31-45 tahun dan satu penderita pada kelompok usia 46-60 tahun. Acinic cell carcinoma 
terdapat satu penderita pada kelompok usia 31-45 tahun.

Tabel 5 memperlihatkan pleomorphic adenoma terdapat 14 penderita laki-laki $(66,7 \%)$ dan tujuh penderita perempuan (33,3\%), sehingga dapat disimpulkan bahwa pleomorphic adenoma lebih banyak pada laki-laki. Hal ini tidak sama dengan laporan Pinkston JA et al. ${ }^{13}$ yang mendapati penderita pleomorphic adenoma perempuan justru lebih banyak daripada penderita laki-laki. Whartin's tumor terdapat lebih banyak penderita laki-laki $(66,7 \%)$ lebih banyak daripada penderita perempuan $(33,3 \%)$ dan ini sama dengan laporan Chahin $\mathrm{F}^{5}$ yang menyatakan Whartin's tumour lebih banyak diderita oleh laki-laki daripada perempuan. Penulis menemukan jumlah penderita acinic cell carcinoma hanya ada satu penderita saja dan berjenis kelamin perempuan. Tidak ditemukan penderita berjenis kelamin laki-laki. Hal ini sama dengan laporan Budiman B.J. yang menyebutkan bahwa perempuan lebih banyak menderita acinic cell carcinoma daripada laki-laki (3:1). ${ }^{8}$

Gambar 1 memperlihatkan tahun pertama (Juli 2012-Juni 2013) terdapat delapan penderita, tahun kedua (Juli 2013Juni 2014) terdapat 12 penderita, sedangkan untuk tahun ketiga (Juli 2014Juni 2015) terdapat 17 penderita. Berdasarkan data tersebut dapat disimpulkan bahwa jumlah penderita tumor kelenjar liur meningkat tiap tahun. Tahun pertama ke tahun kedua meningkat sebanyak 50\% dari delapan menjadi 12 penderita. Tahun ketiga naik sebanyak $41,7 \%$ menjadi 17 penderita. Selama tiga tahun telah terjadi peningkatan lebih dari dua kali lipat (112,5\%) dengan rata rata peningkatan sebanyak 45,3\% pertahunnya. Hal ini tidak sama dengan laporan Ho $\mathrm{K}$ et al. ${ }^{9}$ yang menyatakan bahwa diperkirakan tumor kelenjar liur akan terus meningkat sebanyak 1-2\% pertahun.

\section{KESIMPULAN}

1. Jumlah penderita jumlah tumor kelenjar liur di RSUP Prof. Dr. R.D. Kandou Manado periode Juli 2012-Juni 2015 adalah sebanyak 37 penderita, terdiri dari 30 penderita tumor jinak dan tujuh penderita tumor ganas.

2. Berdasarkan jenis kelamin, tumor kelenjar liur lebih banyak dijumpai pada laki-laki yaitu 22 penderita daripada perempuan yaitu 15 penderita.

3. Berdasarkan kelompok usia, tumor kelenjar liur paling banyak terdapat pada keompok usia 4660 tahun yaitu sebanyak 14 penderita. Paling sedikit pada kelompok usia $<16$ tahun dimana hanya didapati satu penderita saja.

4. Berdasarkan sifat tumor, tumor jinak (81,1\%) lebih banyak dijumpai daripada tumor ganas (18,9\%). Tumor jinak paling banyak dijumpai pada kelompok usia 46-60 tahun (40\%).

5. Tumor kelenjar liur yang paling banyak ditemukan adalah pleomorphic adenoma sebanyak $56,8 \%$ dari semua kejadian tumor kelenjar liur. Pleomorphic adenoma juga merupakan tumor jinak yang paling banyak (70\%) dari semua tumor jinak yang di temukan. Tumor ganas yang paling sering adalah mucoepidermoid carcinoma sebanyak 10,8\% dari seluruh kejadian tumor kelenjar liur dan sebanyak 42,9\% dari seluruh kejadian tumor ganas kelenjar liur.

6. Lokasi tersering tumor kelenjar liur adalah kelenjar parotis (83,8\%). Lokasi tersering tumor jinak kelenjar liur juga pada 
kelenjar parotis. (83,3\%). Tumor ganas kelenjar liur juga memiliki lokasi tersering pada kelenjar parotis $(85,7 \%)$.

7. Pleomorphic adenoma paling banyak pada laki-laki (66,7\%). Whartin's tumour paling banyak terdapat pada laki-laki (66,7\%). Myoepithelioma hanya ditemukan pada laki-laki, basal cell adenomahanya hanya ditemukan pada perempuan, dan oncocytoma hanya ditemukan pada perempuan. Cystadenoma tersebar merata pada kedua jenis kelamin, canalicular adenoma hanya ditemukan pada laki-laki, mucoepidermoid carcinoma paling banyak ditemukan pada laki-laki, adenocarcinoma tersebar merata pada kedua jenis kelamin, sedangkan acinic cell carcinoma hanya didapati pada penderita perempuan.

8. Pleomorphic adenoma paling banyak pada kelompok usia 4660 tahun (33,3\%). Whartin's tumour tersebar merata pada kelompok usia 31-45, 46-60, dan $>60$ tahun. Myoepithelioma hanya ada pada kelompok usia $>60$ tahun, basal cell adenoma dan oncocytoma hanya ada pada kelompok usia 46-60 tahun, cystadenoma tersebar merata pada kelompok usia 46-60 dan $>60$ tahun, canalicular adenoma hanya ditemuka pada kelompok usia 46-60 tahun, mucoepidermoid carcinoma paling banyak pada kelompok usia $>60$ tahun (50\%), adenocarcinoma tersebar merata pada kelompok usia 31-45 dan 46-60 tahun, acinic cell carcinoma hanya ditemukan pada kelompok usia 31-45 tahun.
9. Jumlah penderita tumor kelenjar liur meningkat selama tiga tahun terakhir. Pada tahun pertama hanya terdapat delapan penderita, tahun kedua meningkat sebanyak $50 \%$ menjadi 12 penderita, terus meningkat sebanyak $41,7 \%$ hingga 17 penderita pada tahun ketiga, dengan kenaikan rata rata $45,3 \%$ pertahun.

\section{SARAN}

1. Arsip data rekam medik sebagai sumber data penelitian sebaiknya harus lebih lengkap dan jelas kemudian disimpan dengan baik meskipun arsip tersebut sudah berumur lebih dari tiga tahun sehingga memudahkan peneliti untuk melakukan penelitian khususnya penelitian yang bersifat retrospektif.

2. Pada rekam medik sebaiknya dicantumkan surat keterangan diagnosa berdasarkan laboratorium patologi-anatomi, untuk meningkatkan keakuratan dan kualitas penelitian.

3. Melakukan penelitian yang lebih lanjut tentang tumor kelenjar liur.

\section{DAFTAR PUSTAKA}

1. Kurnia A. Kanker kepala leher dan rekonstruksi. Jakarta: Balai Penerbit FKUI; 2008. h. 73-94.

2. Manuaba TW. Panduan penatalaksanaan kanker solid PERABOI 2010. Sagun Seto; 2010. h. 74-97.

3. Futran ND, Parvathaneni U, Martins RG, Laramore GE. Malignant salivary gland tumors. Dalam: Harrison LB, Sessions RB, Ki-Hong W, editor. Head and neck cancer: a multidiscipilnary approach. Ed. 3. Philadelphia: Lippincott 
Williams \& Wilkins; 2009. h. 589-610.

4. Speight PM, Barret AW. Salivary glands and saliva: salivary gland tumors. Oral diseases. 2002;8:229-40

5. Chahin F. Salivary gland tumors, major, benign. Medscape. 1 Desember 2011. [diakses 25 september 2015]

Available from:

http://emedicine.medscape.com/a rticle/194357-overview\#a04

6. Lee SC. Salivary gland neoplasms. Medscape, 8 Maret 2013. [diakses 25 September 2015]

Available from: http://emedicine.medscape.com/a rticle/852373-overview

7. Lumongga F. Acinic cell carcinoma. USU Repository 2008;2-3. Available from: http://usu.repository.co.id/

8. Budiman BJ. Parotidektomi total pada karsinoma sel asinus parotis. Bagian Telinga Hidung Tenggorok Bedah Kepala Leher (THT-KL) Fakultas Kedokteran Universitas Andalas / RSUP Dr. M. Djamil, Padang 2007;2

9. Ho K, Lin H, Ann DK, Chu PG, Yen Y. An overview of the rare parotid gland cancer. 2011;1 Available from: http://www.headandneckoncolog y.org/content/3/1/40

10. Lisnawati, Stephanie $\mathbf{M}$, Hamdani C. Diagnostic accuracy and cytomorphology analysis of fine needle aspiration of salivary gland. Med J Indonesia. 2012;21;92-6.

11. Sinuraya ES. Registrasi kanker berbasis rumah sakit di rumah sakit kanker dharmais 20032007. Jakarta, laporan kerja sub bagian registrasi kanker bagian penelitian dan pengembangan rumah sakit kanker dharmais pusat kanker nasional departemen kesehatan republik indonesia. 2012: 27, 31, 33, 35, 37, 38.

Available from: http://www.scribd.com/doc/1118 90699/registrasi-kanker-berbasisrumah-sakit-di-rskd-2003-2007/

12. Ito FA, Ito $\mathbf{K}$, Vargas PA, de Almeida OP, Lopes MA. Salivary gland tumors in a Brazilian population: a restrospective study of 496 cases. Int $\mathrm{J}$ Oral Maxillofac Implants. 2005;34:533-36

13. Pinkston JA, Cole P. Incidens rates of salivary glands tumors: Result from a population-based study. Otolaryngol Head Neck Surg. 1999;120:834-40

14. Vargas PA, Gerhard R, Filho VJFA, de Castro IV. Salivary gland tumors in a Brazilian population: a retrospective study of 124 cases. Rev Hosp Clin Fac Med S Paulo 67. 2002;6;271-6 